University of California

Division of Agriculture and Natural Resources

http://anrcatalog.ucdavis.edu

MARTIN H. SMITH, Cooperative Extension Youth Curriculum Development Specialist, University of California, Davis;

CHERYL L. MEEHAN, Staff Research Associate, University of California, Davis; JUSTINE MA, Program Representative,

University of California, Davis; H. STEVE DASHER, 4-H Youth and Community Development Advisor, University of California Cooperative Extension, San Diego County; JOE D. CAMARILLO, 4-H Youth and Community Development Advisor, University of California Cooperative Extension, Madera County; REBEKKA HAUERT, University of California, Davis, Undergraduate Student Curriculum Design Team Member.

\section{Subject Overview and}

\section{Background Information}

Protecting your horse's health begins with providing your horse with proper nutrition, shelter, exercise, and grooming. A horse's diet should consist of plenty of clean water and a mixture of legume hay (such as alfalfa) and grass hay. A horse's nutritional needs depend on its age, size, and breed. The average adult horse will eat 2 to 2.5 percent of its body weight each day. If your horse requires extra nutrition in addition to the hay, a grain mixture may also be fed. Too much grain or not enough forage material can cause intestinal problems, commonly known as colic. Colic can be very serious and is the number one cause of horse deaths. Excessive amounts of grain can also cause swelling in the tissue in your horse's hooves, leading to a condition known as laminitis.

Your horse should have a clean, dry, sheltered place to live in cold weather. It is up to you whether you keep your horse in a barn or out to pasture in mild weather. If your horse is in a stall, it needs plenty of room to be able to turn around, move around, and lie down. Straw or wood shavings make good bedding material. If your horse is out in pasture, it should be provided with access to a covered shelter.
Just like you, your horse needs exercise to remain healthy and happy. It is best to exercise your horse daily. Going for long periods of time without exercising your horse and then forcing your horse to exercise a lot can cause fatigue and even injure your horse. Joint disease and tying-up disease (a muscle problem that makes your horse reluctant to move) are just some of many conditions that can result from improper exercising. It is a good idea to

lunge your horse before going out for a ride, both to help warm up the horse and to spend some of the horse's energy so he or she is easier to control. Lunging involves making your horse walk, trot, jog, or run around in a circle on a lead.

Grooming your horse daily is also very important. You should use a curry comb in circular motions to help remove dirt from its coat and stimulate blood flow to the skin. Then you should follow with a stiffer brush, called a dandy brush, using straight motions. A horse should be brushed before putting a saddle on it, as well as washed and brushed after exercise to remove the sweat from its coat. Proper daily grooming also includes using a hoof pick to keep your horse's hooves clean and free from debris. 
In addition to taking good care of your horse's daily needs, you should also have your horse seen regularly by a veterinarian, even if it doesn't seem sick. Although a veterinarian is an expert on treating sick animals, he or she is also an expert in helping to prevent animals from becoming sick. Some diseases can be prevented through vaccination programs. One such disease is strangles, a highly contagious bacterial infection. Your veterinarian helps keep your horse healthy by knowing what vaccinations your horse needs, answering any questions you may have about horse care, and possibly noticing disease symptoms in your horse that you may not have recognized.

Overall, you should be as observant as possible regarding your horse's physical condition. Any changes in your horse's attitude, behavior, or appearance could be a sign of a health problem.

\section{Activity Concepts and Vocabulary}

- Bacterial infection: A disease caused by germs called bacteria.

- Bacterium (bak-teer-ee-um): An organism that cannot be seen with the naked eye. Some bacteria (germs) can cause diseases. Pneumonia, a disease that affects animals' lungs, can be caused by a bacterium.

- Fungus (fuhng-guhs): An organism (e.g., mold, yeast) that lives and feeds on organic material such as bread, wood, and other animals. A common fungus that affects animals is ringworm.

- Inflammation (in-fluh-may-shuhn): A local reaction of a tissue to irritation that causes pain and swelling.

- Lunging: training a horse to walk, trot, and canter in a circle on a lead line.

- Parasite (par-uh-site): An organism (e.g., bacterium, worm, tick) that receives food and energy from another. A common parasite that affects animals is tapeworm.

- Veterinarian (vet-er-uh-nair-ee-uhn): A doctor who takes care of animals.

- Virus: A type of germ that causes diseases. Rabies is a disease caused by a virus.

- Zoonotic diseases (zoe-eh-notick): An disease that affects an animal that can also be passed to humans.

\section{Life Skills}

- Head: Keeping records, planning and organizing, critical thinking, problem solving, decision making

- Heart: Concern for others, communication, sharing, empathy

- Hands: Teamwork, self-motivation

- Health: Disease prevention, self-responsibility, personal safety

\section{Subject Links}

Science and Language Arts

\section{State Content Standards}

\section{Science}

- Third Grade

- Investigation and Experimentation: 5e

- Fourth Grade

- Investigation and Experimentation: $6 c$

- Fifth Grade

- Investigation and Experimentation: 6h, 6i

- Sixth Grade

- Investigation and Experimentation: 7d

\section{Language Arts}

- Third Grade

- Reading Comprehension: 2.2, 2.6

- Fourth Grade

- Reading Comprehension: 2.3

- Listening and Speaking Strategies: 1.7

- Fifth Grade

- Reading Comprehension: 2.3, 2.4

- Listening and Speaking Strategies: 1.5

- Sixth Grade

- Listening and Speaking Strategies: 1.5

- Speaking Applications: $2.5 b$

\section{Purpose of Activities}

To help youth learn about the proper maintenance and care of horses. Youth will also investigate the causes and symptoms of several horse diseases. 


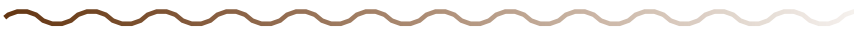 \\ ACTIVITY 1 \\ Monitoring Horse Health Day by Day}

\section{Overview of the Activity}

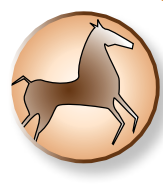

The main goal of this activity is for youth to learn to make good physical and behavioral observations of horses by reading and analyzing descriptive journal entries. Youth will then use these observations to make inferences regarding the health of their horse.

\section{Time Required}

Approximately 90 minutes

\section{Suggested Grouping}

Pairs or small groups of 3 to 4

\section{Materials Needed for Each Pair or Group}

(*Materials provided in curriculum)

- Writing utensils

- Flip chart paper (one piece per group)

- *Health assessment journals

- *Horse disease information sheet

- *Health assessment checklist

\section{Getting Ready}

- Photocopy enough health assessment journals, horse disease information sheets, and health assessment checklists for the groups.

\section{Opening Questions}

Ask the youth to respond to each question below by sharing their ideas verbally and/or by recording them on the flip chart paper provided.

1. What are some ways you can tell when you are sick?

2. What signs might your parents, teacher, friends, or doctor use to recognize that you are sick?

3. What are some things you can do to avoid becoming sick?
4. If your animal is sick, what are some changes you might notice about him or her?

5. What are some of the responsibilities you have to keep your pet or project animal healthy?

\section{Procedure (Experiencing)}

- Volunteer Tip: Set up the following scenario for the youth: The youth in each group will be playing the role of a horse owner. Each group will receive one of the health assessment journals, one day at a time. As a group, the youth will go through the journal entry of each specific day and record important facts onto the health assessment checklist they have been given. At the end, using the checklists they have made, they will compare their findings with the horse disease information and draw a conclusion regarding what disease, if any, their horse has.

1. Give each group of horse owners Journal Entry 1 from their health assessment journal. The group should read the entry and record important findings on their health assessment checklist.

2. When the groups have completed Journal Entry 1, take away that journal entry and give them Journal Entry 2. Then have them read the entry and record important findings on their checklist.

3. Continue this pattern for the remaining days until each journal entry has been assessed.

4. When the group is done with the last day, remove this entry and pass out the horse disease information sheet. Have the groups review the data that they recorded on their health assessment checklist and record their diagnosis of their horse's symptoms along with the reasons why they chose that diagnosis.

\section{Sharing, Processing, and Generalizing}

Have each group share their diagnosis and indicate which parts of their checklist helped them make that determination. Follow the lines of thinking developed through the general thoughts, observations, and questions raised by the youth. If necessary, use more targeted 
questions as prompts to get to particular points, such as the following. Ask the youth to respond to each question below by sharing their ideas verbally and/or by recording them on the flip chart paper provided.

1. What might be some advantages to keeping a daily health assessment journal for your horse?

2. What are some examples of the symptoms you used to tell you when to be concerned with your horse's health?

3. What do you think might happen if you ignored those symptoms and didn't seek veterinary care for your horse?

4. Check the groups' diagnosis of their horse with the answer key. If there are any discrepancies, have the youth discuss what lead them to their conclusion.

\section{Horse Disease Diagnosis Key}

- Betsy: colic

- Patches: joint disease

- Winnie: tying-up disease

- Mr. Darcy: strangles

\section{Concept and Term Introduction}

Volunteers need to ensure that the concepts and terms

\section{bacterial infection, bacterium, fungus, inflammation,} lunging, parasite, veterinarian, virus, and zoonotic

diseases have been introduced.

- Note: The goal is to have the youth develop these concepts through their exploration and define the terms using their own words.

\section{Concept Application}

An application for these skills is presented in Activity 2 of this unit. Youth who own a horse may apply Activity 2 to their own pet, while youth who do not own a horse may seek permission from a friend or family member to use their horse in this exercise.

\section{References}

Bayer Equine Connection Web site, http://www. bayerequineconnection.com/.

Blazer, D. A Horse of course. Pelham Saddlery Web site, http://www.pelham-saddlery.com/horse_column/ exercise.html.

Clayton, H. Studying the hock: One of the horse's most complex and crucial locomoter structures. Hoofcare and Lameness 78:48-49. Hoofcare and Lameness Web site, http://www.hoofcare.com/article_pdf/ HoofcareClaytonHock.pdf.

eHow.com. How to tack a horse. eHow.com Web site, http://www.ehow.com/how_180_tack-horse.html.

Ruggiero, B. 2002. Horse colic. Essortment.com Web site, http://nyny.essortment.com/horsecolic_rdfg.htm.

Evans, J. W. 2001. Horses. 3rd ed. New York: Henry Holt.

Hill, C., and R. Klimesh. 1997. Horse health care: A step by step photographic buide to mastering over 100 horsekeeping skills. North Adams, MA: Storey.

Microsoft Encarta Encyclopedia. 2002. Horse. CD-ROM. Seattle: Microsoft.

Horses and Horse Information Web site, http://www. horses-and-horse-information.com.

Microsoft Encarta Encyclopedia. 2002. Horsemanship. CDROM. Seattle: Microsoft.

Huntington, P., J. Myers, and E. Owens. 2004. Horse sense: The guide to horse care in Australia and New Zealand. Collingwood, Australia: Landlinks Press.

Huntington, P., and S. Valberg. 2000. Tying-up in horses. Petalia Web site, http://www.petalia. com.au/Templates/StoryTemplate_Process. cfm?specie=Horses\&story_no=1691.

Pfizer Animal Health. Strangles information page. Pfizer Animal Health Web site, http://www.cyberhorse.net. $\mathrm{au} / \mathrm{csl} /$ strangles.htm.

Purina Mills Horse Web site, http://horse.purinamills.com/.

Biomedia Laboratories. Degenerative joint disease. Biomedia Laboratories Recovery EQ Web site, http:// www.recoveryeq.com/degenerative_joint_disease.htm.

Penzance Equine Solutions. The skeletal system of the horse. HorseSource Online Web site, http://www. kersur.net/ santa/skeletalsystem.html.

The Ultimate Horse Site Web site, http://www. ultimatehorsesite.com. 


\section{HEALTH ASSESSMENT JOURNALS}

\section{Journal 1}

Horse Name: Betsy

Breed: Thoroughbred

Gender: Female

Age: 2 years

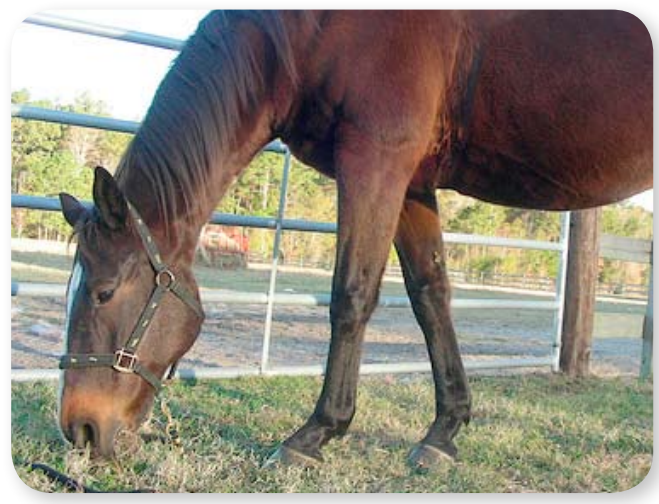

Brittney Hogan

http://www.flickr.com/photos/brittanylynae/2251873904/

\section{Journal Entry 1}

When I went to visit Betsy today at sunnyvale Farms, she seemed to be in a pretty good mood. I think she likes being boarded there. She whinnied when I came up to her stall and let me pat her nose. She sniffed in my jacket pockets, probably looking for treats. I didn't have any carrots or apples to give to her today. It looked like Betsy had eaten most of her hay already, so 1 doubt she was really hungry. The barn manager is the one who gives her the roughage part of her diet each day, and it's up to me to give her any grain or treats she might need. My project volunteer says Betsy only needs a couple of small scoops of grain each day.

I did my overall health examination of Betsy before I groomed her and put on her saddle and bridle. Her pulse (heart rate) was 35 beats per minute and her respiration rate (breathing rate) was 10 breaths per minute. Her temperature was $100^{\circ} \mathrm{F}$. Her eyes were clear and bright and her ears were clear as well. Her nose was moist, but there was no discharge. Her coat was very dusty but she didn't have too many tangles in her mane or tail. She cooperated well when I made her lift her hoof to use the hoof pick. There were some big rocks stuck in her front right hoof. She didn't urinate while I was with her, but her feces in the stall looked typical.

We went for a short ride around the ranch. We walked for a while, then did some loping, and then walked again. I didn't notice any problems with her gait. When we got back, I led her out to the pasture to let her graze or run around as much as she wanted. I mucked out her stall which wasn't all that dirty. After about an hour I put Betsy back in her stall and brushed her again. She only got a little sweaty from the exercise. I didn't spray her down with water since it's a cold day. 


\section{Journal 1}

Horse Name: Betsy

Breed: Thoroughbred

Gender: Female

Age: 2 years

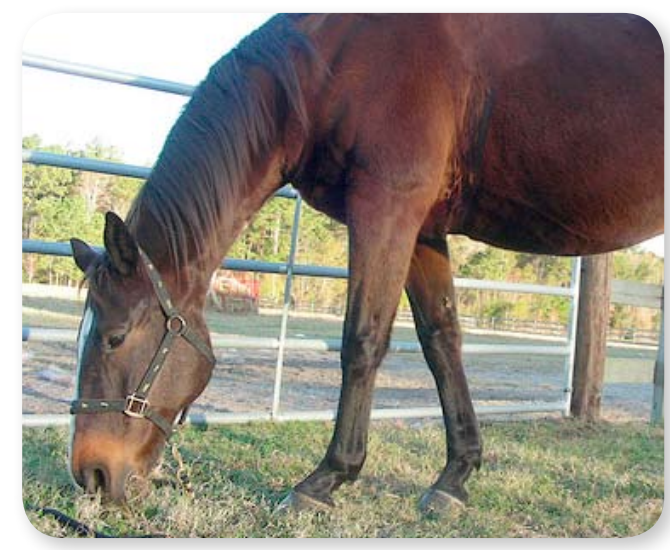

Brittney Hogan http://www.flickr.com/photos/brittanylynae/2251873904/

\section{Journal Entry 2}

Betsy seemed eager to get out and run today. She whinnied when I approached her and let me groom and put her tack on very easily. It was as if she knew if she cooperated she would get to run outside sooner. It didn't take long because her coat was very clean and shiny. She wiggled her ears a lot, but when I looked at them there didn't appear to be any problems. While grooming her I noticed that her eyes were a little drippy. The discharge looked clear. Her nose wasn't moist today. Her pulse was 45 and her respiration rate was 12. I didn't take her temperature today. The furst thing 1 did when I led Betsy outside was make her lunge. Lunging usually helps her get some of her energy out so I don't have such a hard time controlling her during my ride. She bucked a few times on the lead rope and didn't seem to want to trot. She either wanted to walk or canter.

1 rode her for a fairly long time after that. We did lots of cantering and some running. There were no changes in her gait. Betsy seemed to love it.

When we got back I sprayed Betsy down with the hose since she got really sweaty. The barn manager let me borrow a blanket that would keep her warm after the little bath. I turned Betsy out to pasture so I could muck her stall. Her feces looked the same. She had eaten all of her hay and grain mixture. I put her back after about 30 minutes. 


\section{Journal 1}

Horse Name: Betsy

Breed: Thoroughbred

Gender: Female

Age: 2 years

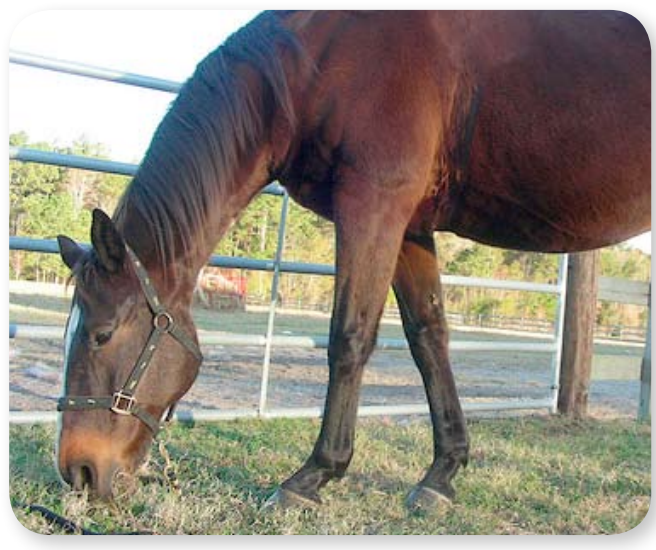

Brittney Hogan

http://www.flickr.com/photos/brittanylynae/2251873904/

\section{Journal Entry 3}

Betsy seemed a little more nervous than usual when I came to see her today. The weather has been a little stormy, and I don't think Betsy likes thunder. There were a lot of flies in the barn today, and I don't think she liked that either. She swished her tail and wiggled her ears a lot. There was some dirt in her ears, so I cleaned them out with some cotton balls. At least her eyes were clear of any discharge and her nose was dry. I groomed her and she cooperated when 1 checked her hooves. Her coat and hooves looked good. She seemed a little impatient when 1 put on her saddle and bridle and didn't stand as still as she normally does. Her pulse was 44 and her respiration rate was 10. Her temperature was 1010F.

It looks like she didn't eat very much hay today. She did eat a carrot when I offered it to her, though.

Since Betsy was so nervous, I made sure to lunge her so she wouldn't try to buck during our ride. She jogged around the circle on the lead and got three or four bucks out. She didn't listen to all of my directions when 1 told her to speed up or slow down. Her gait was a little uneven, and it seemed like Betsy was holding her neck more stiffly that usual.

When we went for our ride, she seemed to spook very easily. She almost started to buck when a small squirrel scampered down a tree and across our path. We walked and trotted, but I didn't want to go any faster than that.

1 let Betsy stay out in the fleld for half an hour after our walk while I mucked her stall. It seemed really dirty, and I had a lot of feces to clean up. I led her back to her stall and brushed her again. 


\section{Journal 1}

Horse Name: Betsy

Breed: Thoroughbred

Gender: Female

Age: 2 years

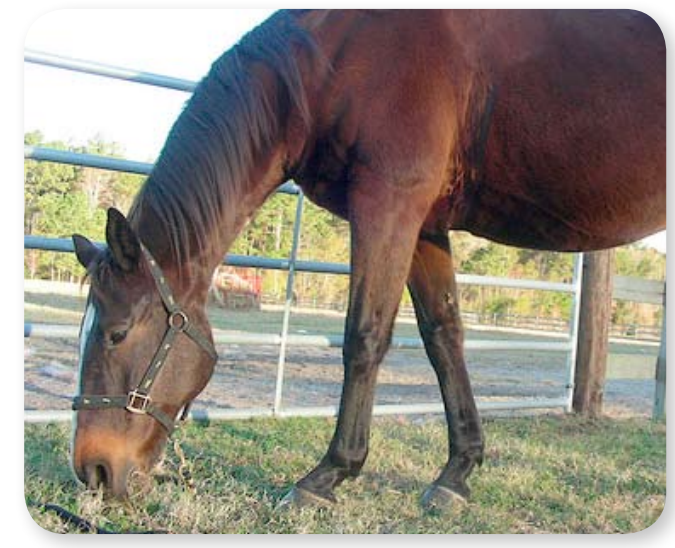

Brittney Hogan http://www.flickr.com/photos/brittanylynae/2251873904/

\section{Journal Entry 4}

Betsy still doesn't seem to like the weather and isn't eating very much. My project volunteer and I decided to add a little more grain to her diet to see if that makes her more interested. Her pulse was 50 and her respiration rate was 17. Her temperature was 101ㄷ․ While grooming I noted that Betsy's eyes, ears, and nose were all clean, though her nose was a bit moist again. Her coat was a bit dirty and her mane was tangled again.

Betsy did her lunging well today. She followed my directions much better. Her posture and gait looked better, too.

On our ride today I went really slowly because I didn't want to have any accidents with the weather still like it is. Betsy didn't seem quite as jumpy. I decided to go through the orchard because I think it's pretty, and I thought Betsy might like to see someplace different. I'm not sure if it was a good idea because Betsy kept trying to stop and eat the weeds. She got a few mouthfuls in here and there before I could pull her head up.

1 brushed Betsy and let her stay out in pasture for an hour when we got back. I mucked out her stall (which didn't have much poop in it), put her back, and groomed her. She was a little sweaty and snorting when I left. 


\section{Journal 1}

Horse Name: Betsy

Breed: Thoroughbred

Gender: Female

Age: 2 years

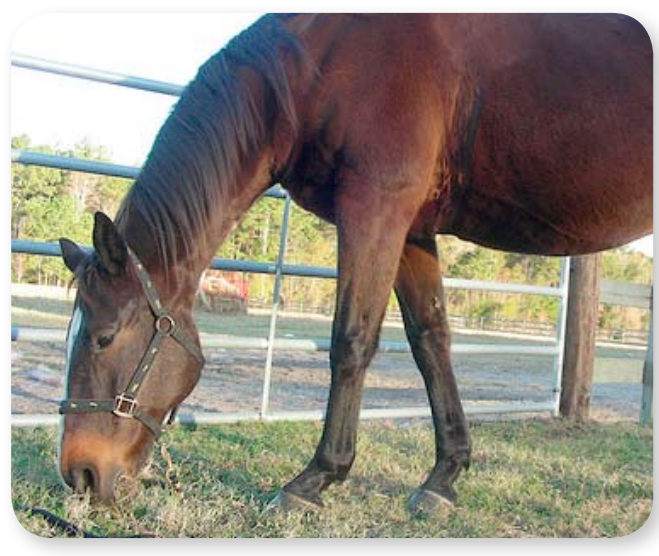

Brittney Hogan

\section{Journal Entry 5}

Today when I walked up to Betsy's stall she didn't even seem to notice me.

she looked very sweaty and out of breath. She was even kicking at the sides of stall. I watched her for a while and she never seemed to stand still. She would lie down and get up, then lie down again, over and over. She hadn't eaten any of the hay. Her coat was very dirty and covered in straw, and her mane and tail were very tangled. It didn't look like she'd gone to the bathroom during the night. I think she was snorting more than she usually does. Her ears turned from pointing forward to backward often, and she kept her eyes open very wide. Her pulse was 61 and her respiration rate was 29. Her temperature was 101ㄷ. I went to go get the barn manager. 
Journal 2

Horse name: Patches

Breed: Quarter horse

Gender: Male

Age: 10 years

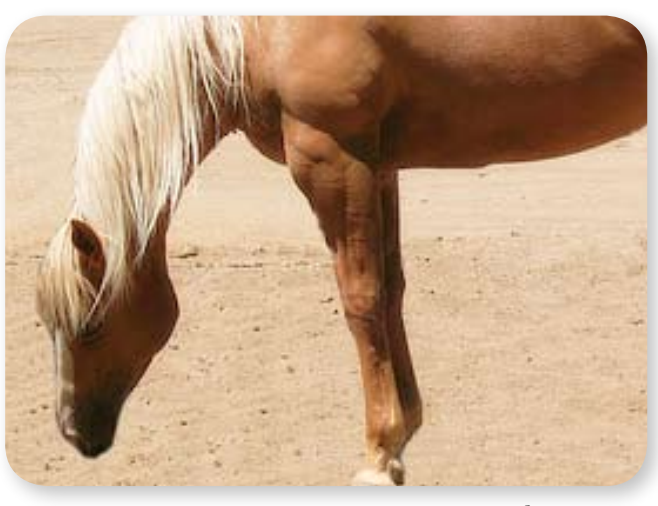

Linda Hartman http://www.flickr.com/photos/lindaburnett/1188159501/

\section{Journal Entry 1}

Patches was running in wide circles when I went out to see him before school this morning. Patches spends all his time out there now that it's summer and the weather is always nice and the nights aren't very cold.

I fulled the food trough with alfalfa hay and changed the water in the water trough. There were a lot of clumps of hay floating in it, along with a few flies.

Later, after I returned from school and funished my homework I went out to ride patches. He was grazing when I furst walked out there, but he trotted quickly and smoothly over to the fence. I gave him some apple slices and two carrots. He gobbled them up quickly. His mouth was dripping with drool, and he got my jacket dirty. His eyes looked slightly cloudy. His nose and ears looked clean. I got my saddle and other riding gear out of the shed, put the halter on him and tied him up to the post. He was really dirty, but I only brushed him for a minute or two because I wanted to get riding. I forgot to check his hooves. I did check his pulse and respiration rate, which were 37 beats per minute and 11 breaths per minute. Patches' temperature was $100.50 \mathrm{~F}$.

We rode the trail that goes behind our garage, past our guest house, and down to the creek. We walked for the furst fuve minutes and trotted the rest of the way to the creek. Patches stopped to urinate once, which seemed to take a long time. From what I could tell it looked yellow. I let him wade in the creek for a little while and then we jogged back home.

Patches was very sweaty after our ride, so I hosed him off and brushed him really well before 1 went inside for dinner. 


\section{Journal 2}

Horse name: Patches

Breed: Quarter horse

Gender: Male

Age: 10 years

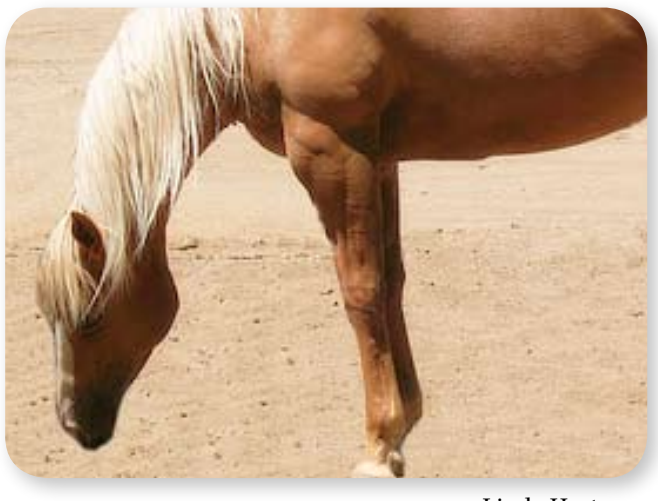

Linda Hartman http://www.flickr.com/photos/lindaburnett/1188159501/

\section{Journal Entry 2}

My mom fed Patches this morning because I was running late and needed to catch the school bus. She said he ate almost all his hay from yesterday and flgures he must be getting some good exercise and working up an appetite being outside all the time. He has appeared more muscular lately, in my opinion.

I went out to ride him after dinner, just a little bit before sunset. He was waiting near the hitching post to get his gear put on. He was standing differently than normal, like he was leaning back a little. I checked his hooves and picked out a few rocks and a lot of dirt. He had dirt all through his coat and even in his ears. His mane and tail were very tangled. I brushed him pretty well, but didn't have time to get all the tangles out. His eyes still look cloudy. His nose was moist. His temperature was 99.3ㄷ․ His pulse (heart rate) was 32. His respiration rate (breathing rate) was 9 .

When I climbed into the saddle, he shifted from foot to foot, as if I weighed a lot. Maybe I am growing pretty fast right now. We just went for a short trot out to the big oak tree and back, since it was getting dark. He didn't try to speed up on the way back like he usually does.

He wasn't very sweaty or out of breath when I groomed him once more before bed. I gave him an extra carrot and patted his nose before I said good night. 


\section{Journal 2}

Horse name: Patches

Breed: Quarter horse

Gender: Male

Age: 10 years

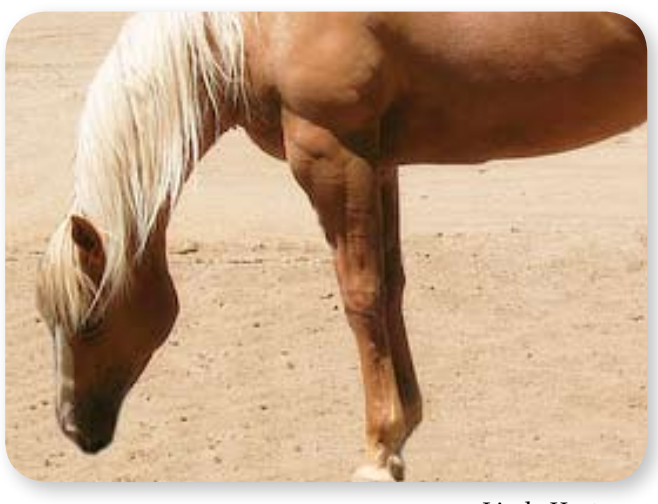

Linda Hartman http://www.flickr.com/photos/lindaburnett/1188159501/

\section{Journal Entry 3}

This morning when I put Patches' food out, he didn't hurry right over. I watched him walk over, and I think he might have been limping a little. His water dish looked clean, so I didn't change it.

After school I went right out to see Patches. Hejogged to me and ate my apples, but I think I noticed him limping again. It seems like he's relying on his front left leg more than his front right. I went inside to tell my mom and dad, and they came out to see, too. They noticed the same thing I did. We tied him up and checked his hooves, which were free from debris. We checked his leg for any swelling and didn't notice any. His pulse was 31 and his respiration rate was 9. His temperature was 101.70F. Mom said it might be best if I gave patches the night off.

I groomed Patches for a long time and talked to him about my day. I think he might have been sad because he didn't seem to want to look straight at me. Hejust stared straight ahead. His eyes were a little cloudy and his ears were droopy. His nose was dry. I hope he's not depressed. He has been eating, and his feces look typical too. 
Journal 2

Horse name: Patches

Breed: Quarter horse

Gender: Male

Age: 10 years

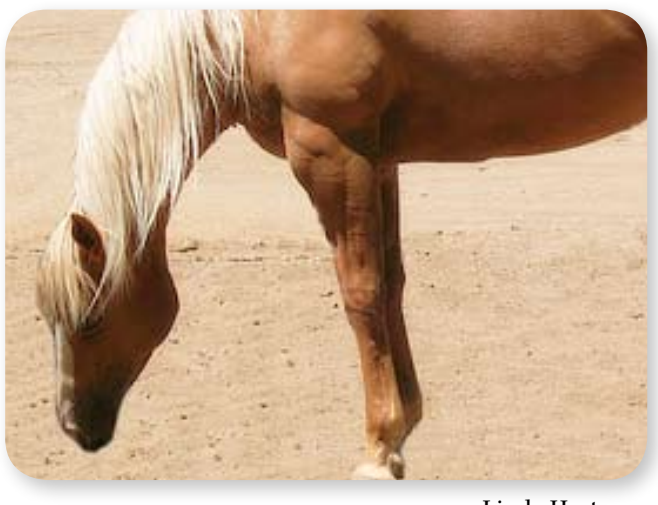

Linda Hartman http://www.flickr.com/photos/lindaburnett/1188159501/

\section{Journal Entry 4}

I went out to feed patches this morning and noticed him limping again.

There was some hay left over from yesterday, so I only gave him part of his new hay. I changed his water.

patches didn't seem very excited when I put the halter and lead rope on him. He walked with his head down. He blinked his eyes a lot. His nose was moist and his ears were clean. I led him around in a circle for a minute in one direction and then made him change directions. He was very hesitant When turning around and didn't want to move at furst. He took a couple steps and then stopped. He repeated that two more times before he walked for me. I still saw the limp on the front right leg.

1 tied patches up to the post and groomed him. While brushing his chest and legs I noticed that his right front carpus looked bigger than the left. 1 felt the bigger carpus with my hand, and it felt a little hot. The rest of him felt hot to the touch also, so that was probably due to the sun. I took his temperature, which was 102.5ㄷ․ His heart rate was 39 and his breathing rate was 14. There was no change in his body wastes. 
Journal 2

Horse name: Patches

Breed: Quarter horse

Gender: Male

Age: 10 years

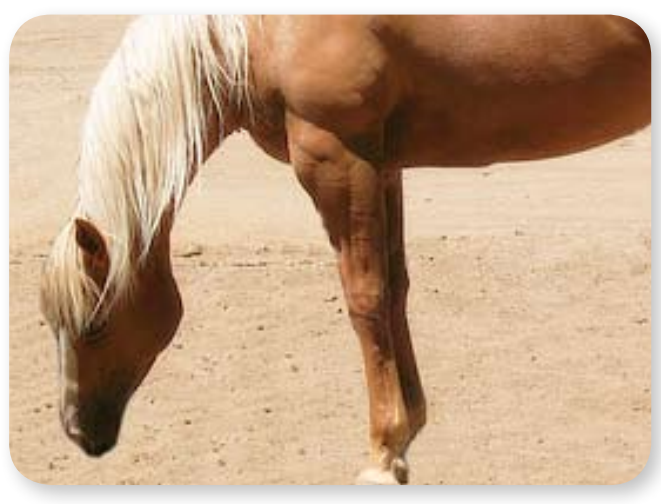

\section{Journal Entry 5}

Mom and Dad went out to check Patches with me today. He stood very still when we approached and had his front right leg bent. They agreed that his knee joint looked swollen and that it was probably the reason he was limping. 1 checked his pulse, which was 50. His breathing rate was 17. His eyes were cloudy and had some clear discharge. His nose was moist and his ears were clear. I started my weekend chore of picking up the yard. I went around shoveling all the horse poop into a wheelbarrow. The feces hadn't changed. I noticed that we had some gopher holes in the yard that weren't there last week. I didn't see any gophers though. 
Journal 3

Horse Name: Winnie

Breed: Appendix (Quarter horse/Thoroughbred cross)

Gender: Female

Age: 6 years

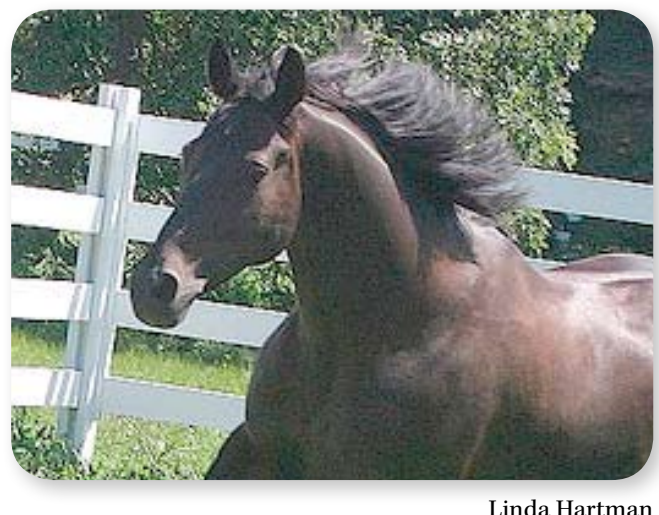

Linda Hartman http://www.flickr.com/photos/lindaburnett/1188159501/

\section{Journal Entry 1}

I went to copperwood Stables early this morning to visit Winnie. Someday I hope I have enough money to have my own stable so I won't have to travel to see my horse.

Winnie was munching on some hay when I walked up to her stall. She was standing up straight and had her ears perked forward. Her eyes were clear and alert. Her nose was dry and soft. Her coat was clean except for her legs, which were splashed with mud. The wood shavings that we put down in her stall were a little muddy too. I used the curry comb to help get the caked mud off of Winnie's legs, and then gently brushed her all over. She was a bit excitable while I was in the stall, and would keep turning in circles, making me walk around her several times to get all of her groomed. I picked the dirt from her hooves and put on her harness, blanket, and saddle.

First I walked Winnie to the Lunging ring and had her trot in circles. Her gait was a little bouncy. I lunged her for 10 or 15 minutes and then walked with her to the main arena. I had Winnie trot, then lope, then gallop around the arena. After that we did some jumping. The bar was fairly low and we had no trouble.

After hosing Winnie off, I turned her out into the pasture for a half hour. In the meantime I cleared all the dirty wood shavings and body waste from her stall. I checked her feces before I threw it away, and didn't see any worms. (she had worms last month.)

I gave Winnie some alfalfa hay and a small bucket of grain when I put her back in her stall. She had a good appetite. I took her pulse (heart rate) and respiration rate (breathing rate), which were 38 beats per minute and 16 breaths per minute. Her

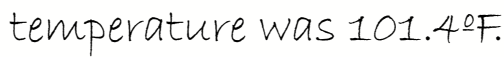




\section{Journal 3}

Horse Name: Winnie

Breed: Appendix (Quarter horse/Thoroughbred cross)

Gender: Female

Age: 6 years

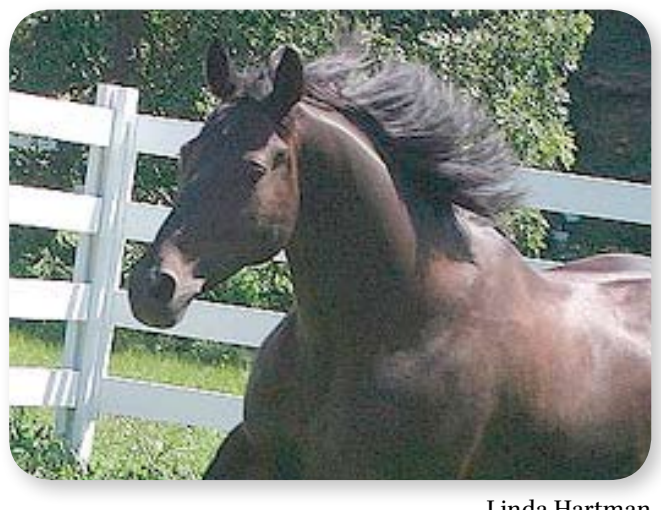

Linda Hartman http://www.flickr.com/photos/lindaburnett/1188159501/

\section{Journal Entry 2}

1 got to copperwood around 3 this afternoon. I brought Winnie a special new blanket to keep her warm after her baths now that it's October. I let her sniff the blanket as soon as I walked up to her. She was suspicious at furst, probably because she didn't recognize what I had in my arms. She neighed and jumped backward at furst, twisting her neck away from me, then timidly approached me with nostrils flaring to sniff. I think the blanket passed inspection.

I cleaned out Winnie's eyes because they had a bit of gunk in them. I wiped her ears out too, just as a precaution. Her nose looked clean. I took her pulse and found that it was 48. Her breathing rate was 17. Her temperature was 102F.

1 groomed Winnie quickly and checked her hooves. She was very clean, but a little sweaty already. I had put on her gear and started to lead her out of her stall when she just stopped. She would not budge for at least two minutes no matter how hard I tugged on her lead rope. Then for no apparent reason, she started walking quickly as if nothing was the matter.

We walked into the main arena and loped for 15 minutes or so. Winnie didn't run as smoothly as she usually does, and it hurt my legs and butt to try to keep my riding posture.

I put Winnie back in her stall and groomed her one more time. She didn't even look at the apples I waved in front of her. I left them on top of her alfalfa and went home. 
Journal 3

Horse Name: Winnie

Breed: Appendix (Quarter horse/Thoroughbred cross)

Gender: Female

Age: 6 years

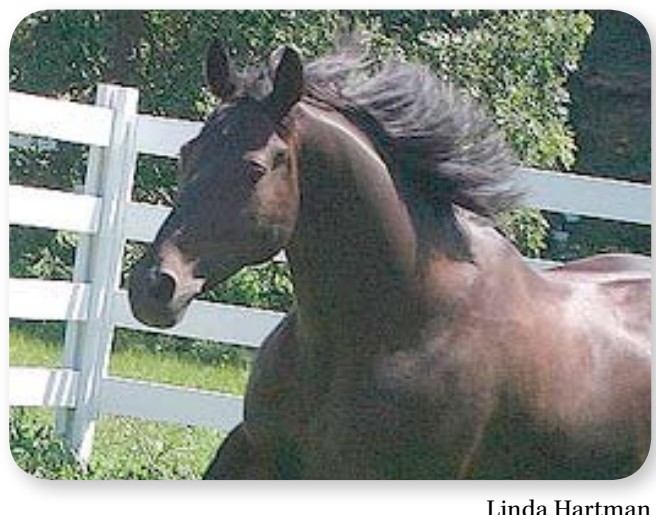

Linda Hartman http://www.flickr.com/photos/lindaburnett/1188159501/

\section{Journal Entry 3}

They started housing a new horse next to Winnie at the stables. Her name is Firecracker and she is very noisy and active, and I think it's annoying Winnie. When I came to see Winnie today she was kicking at the side of her stall with her back legs on the side Firecracker is on. Winnie had her ears back and kept opening her mouth and curling her lips. Firecracker and Winnie were neighing back and forth. The barn manager says the girls should be used to each other after a day or two, and not to worry.

1 led Winnie outside and tied her to a post to do her health check and grooming. She urinated a lot as soon as we got outside. Her pulse was 59 and her respiration rate was 20. Her temperature was 102.1ํ‥ Her eyes were wide but clear. Her nose was dry and soft. 1 found a couple small black specks in her ears, which I washed out with a damp cloth. Her coat and skin look good.

After grooming Winnie, I tried to mount her, but she turned her neck and nipped at my arm with her teeth. I scolded her and gave her a tug on the lead rope. I was able to mount the second time. We jogged to the arena and did some laps at a lope. Her gait was stiff, just like yesterday. I let her gallop, because she often thinks that is more fun. When 1 led her to a jump, she stopped abruptly 10 yards from the jump. Then no matter how much 1 kicked she wouldn't start up again until at least 5 minutes later.

I turned her out to pasture while I mucked her stall and gave her daily alfalfa and grain rations. 


\section{Journal 3}

Horse Name: Winnie

Breed: Appendix (Quarter horse/Thoroughbred cross)

Gender: Female

Age: 6 years

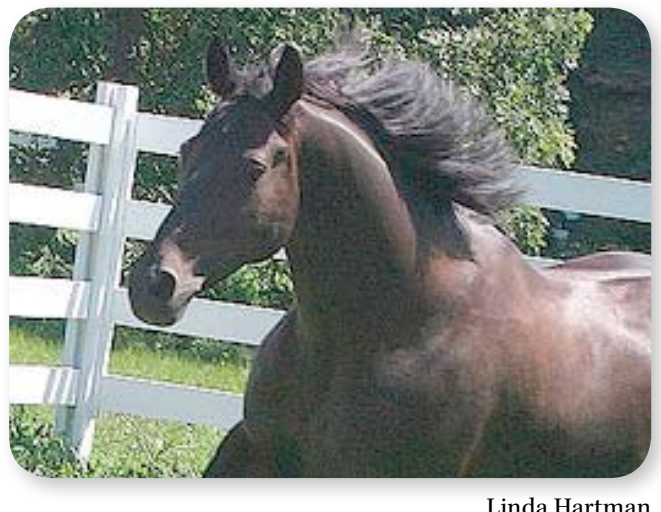

Linda Hartman http://www.flickr.com/photos/lindaburnett/1188159501/

\section{Journal Entry 4}

Firecracker and Winnie were snorting at each other when I came to visit this afternoon. It stopped as soon as I entered Winnie's stall. I took her pulse, which was 45, her breathing rate, which was 20, and her temperature, which was 101.80F. She stood very still for me. I walked around her to examine her coat, keeping one hand on her at all times so she wouldn't get scared. Her coat looked perfect, but I thought I saw her skin twitching near her shoulders. Her eyes, nose, and ears all looked clean. 1 brushed her and picked her hooves. She had some feces in them. There were feces all over the floor of the stall and it appeared she had been stamping through it and moving in circles.

I put on Winnie's tack and led her out to lunge. She didn't limp at all when we walked. When we got to the gate of the arena, she stopped walking abruptly. She wouldn't move when I tugged on her lead rope. A nearby rider suggested I slap Winnie on the rump, so I did. That didn't help. She just moved her head up and down like she was nodding at someone. I funally got her to turn, and we walked around the outside of the arena very slowly. Winnie stepped very gingerly.

1 took her out to the fueld so I could clean her stall. She was standing very close to the gate, waiting, when I returned to lead her back inside. She ate the new hay I gave her eagerly. 


\section{Journal 3}

Horse Name: Winnie

Breed: Appendix (Quarter horse/Thoroughbred cross)

Gender: Female

Age: 6 years

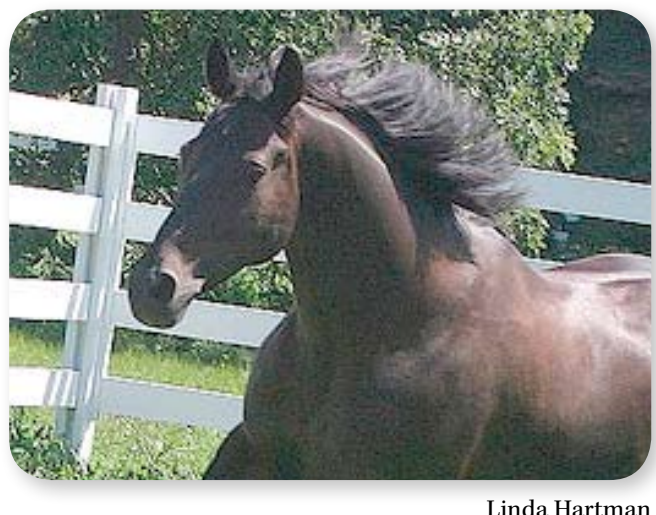

Linda Hartman http://www.flickr.com/photos/lindaburnett/1188159501/

\section{Journal Entry 5}

Winnie wouldn't even leave her stall when I came to see her today. Firecracker was being very quiet next door. Winnie was very sweaty and standing awkwardly. She paced slowly back and forth and then would stand very still with her neck stretched out. She looked skinnier to me. Her nose was wet and her eyes had some clear discharge draining. When I put her harness on she froze and wouldn't follow me out of the stall. I looked at all of her joints and didn't see any swelling. 1 took her temperature and found it to be 103.2ㄷ. Her pulse was 57 and her breathing rate was 18 .

I stood with Winnie for a long time just patting her nose and talking softly to her. Periodically she would shiver and tremble but was always standing very still. I brushed her and tried to check her hooves, but she wouldn't lift her leg up. Finally I forced her to pick her leg up, but she put it back down immediately. I think it was painful for her. I didn't see anything in her hoof during that instant.

I brought Winnie her food for the day, since it looked like she'd eaten most of yesterday's food. She started eating immediately. After an hour or so I tried to walk her outside again. This time she cooperated but walked very slowly. We walked out to the arena fence and around the outside of the arena, and then back to the stall. She went to the bathroom while we were walking, and I didn't see anything out of the ordinary in her waste. Winnie was very out of breath when we returned to her stall. I brushed her again and put her new blanket on. 


\section{Journal 4}

Horse Name: Mr. Darcy

Breed: Arabian

Gender: Male

Age: 11 Months

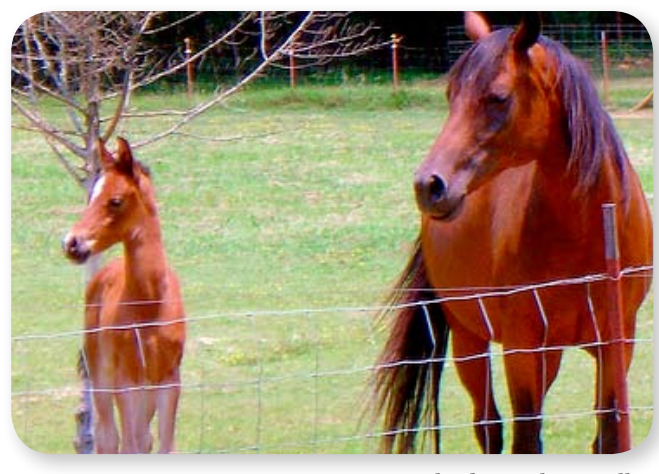

Belinda Hankins Miller

\section{Journal Entry 1}

Mr. Darcy was a bad boy this morning. He managed to dump out his water bucket and go to the bathroom in the fresh hay he was supposed to eat. Then he pulled his blanket into the whole mess. I told him he'd been bad, but he always thinks everything is a game. He just nuzzled me with his nose and nibbled my hands with his lips. There was no way he was getting a treat after the mess he had made.

1 Led Mr. Darcy out to the pasture and let him run around while I mucked out the stall. There was a lot of poop in there, and I saw a couple white worms. We're giving Mr. Darcy some deworming medication right now. I gave him fresh straw as bedding and put some new alfalfa hay in there to eat. I used two clips to secure his water bucket to the other side of the stall, which might work better.

At the end of the day I put Mr. Darcy back in his stall and took his vitals. His pulse was 44 and his respiration rate was 16 . His temperature was 100.2F. I checked his eyes, nose, and ears, which all looked clean. None of his joints looked swollen. I picked his hooves and gave him a good brushing. 


\section{Journal 4}

Horse Name: Mr. Darcy

Breed: Arabian

Gender: Male

Age: 11 Months

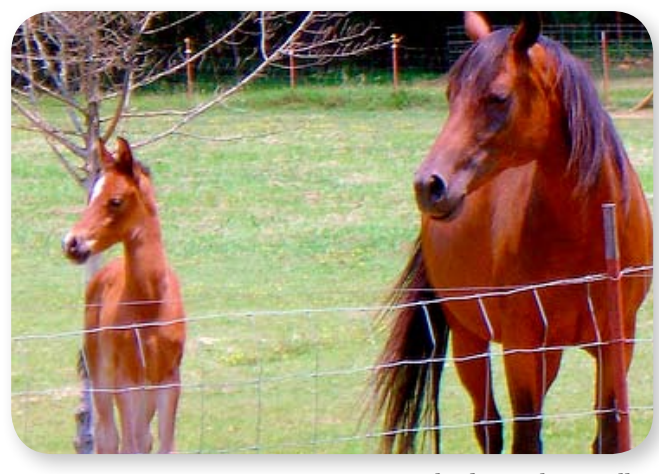

Belinda Hankins Miller

\section{Journal Entry 2}

Mr. Darcy looked great today. He is really starting to full out. I can't wait until he gets big enough to ride. I know I have a while to wait, since my 4-H volunteer says horses may still be growing at 3 or 4 years old.

I practiced lunging Mr. Darcy on the lead rope today. He fought the pull of the rope if it seemed like I was tugging too hard, but overall he did well. His gait looked smooth and comfortable. He moved from a walk to a trot to a canter with ease. We practiced starts and stops, too. He doesn't always respond to the "whoa" command immediately.

I Let Mr. Darcy play in the pasture all day today. He spent a lot of time bothering our other horses by running circles around them. They typically just ignore hím.

I cleaned the dirty straw out of Mr. Darcy's stall and gave him fresh food and water when I put him back in the evening. I groomed him and checked his hooves, joints, and vital signs. His pulse was 42 and his breathing rate was 19. His temperature was 100.70F. His eyes, ears, and nose were clean. There were no signs of worms in his feces. That will be nice to tell the veterinarian during our appointment next week. 


\section{Journal 4}

Horse Name: Mr. Darcy

Breed: Arabian

Gender: Male

Age: 11 Months

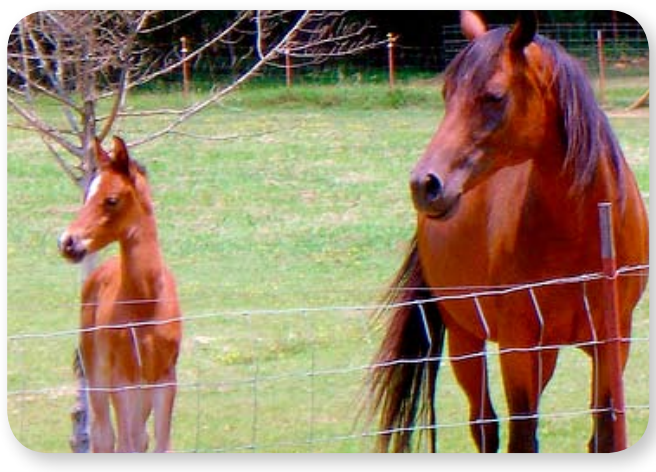

Belinda Hankins Miller http://www.flickr.com/photos/ninjapoodles/535301561/

\section{Journal Entry 3}

Mr. Darcy was already out in the pasture when I came home from school today. 1 joined him in running around for a while and then harnessed him. I tied him up and got his grooming stuff out. When I started brushing him, I noticed right away that he was sniffling. There was a yellow-looking discharge draining from his nose. 1 wondered if horses got allergies like I did, but I didn't notice any watering in his eyes, which is how I always know I have allergies. His ears also looked clean.

I took Mr. Darcy's temperature and found that it was 102.50 F. His pulse was 43 and his breathing rate was 15. He looked slightly uncomfortable and kept stretching his neck out while I was working with him. I checked his hooves and picked out some dirt and grass. His joints didn't appear swollen.

1 left Mr. Darcy tied up and went to tell my parents what I saw. We decided we should put him in the smaller pasture by himself and at some distance from the other horses, just in case he was coming down with something.

I went to his stall and threw out all the straw and all the leftover food. I dumped the water and cleaned the bucket really well with soap. I sprayed down the empty stall with some water and some bleach and left it to dry. My mom said we should leave the stall empty all day and all night. 


\section{Journal 4}

Horse Name: Mr. Darcy

Breed: Arabian

Gender: Male

Age: 11 Months

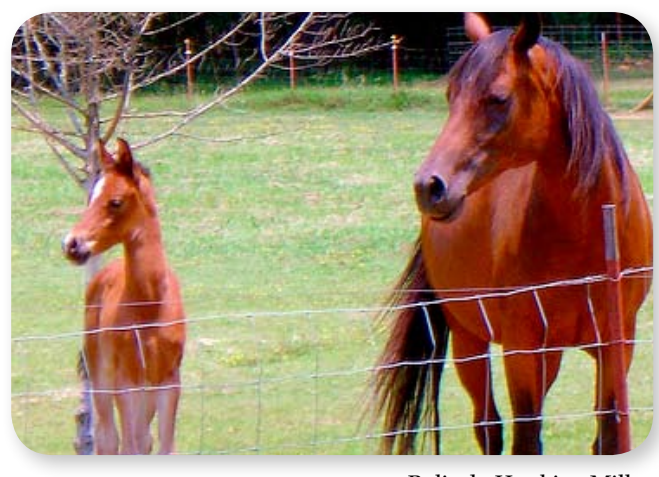

Belinda Hankins Miller

\section{Journal Entry 4}

Mr. Darcy neighed at me when I approached him the next morning. I don't think he appreciated being alone. He had a nice sheltered area covered in straw that he could sleep in last night, so I don't think he could have been uncomfortable or cold. I tied him up and took his temperature, which was 103.0F. His pulse was 44 and his breathing rate was 16. He was still suiffling.

Mr. Darcy's eyes looked drippy with clear liquid and his nose was drippy with yellowish mucous. His ears were clear. His coat was dirty and he had some straw in his mane. I brushed him and cleaned his hooves. 1 untied him and went sprinting out into the middle of the fleld to see if he would follow me. Usually he likes to play that game, but today he seemed slower at catching up with me. At least he did follow me. His gait was smooth and comfortable looking. I checked the fleld for feces and didn't find any.

I gave Mr. Darcy some fresh hay and a small bucket of grain before I had to leave for my friend's birthday party. He didn't look too interested in eating. 


\section{Journal 4}

Horse Name: Mr. Darcy

Breed: Arabian

Gender: Male

Age: 11 Months

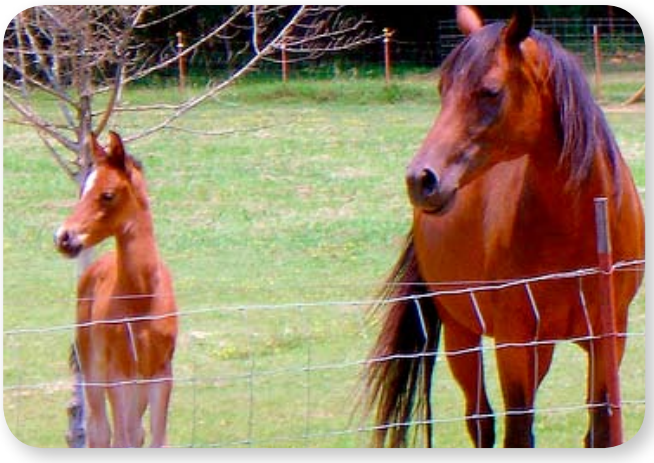

Belinda Hankins Miller http://www.flickr.com/photos/ninjapoodles/535301561/

\section{Journal Entry 5}

I checked on Mr. Darcy furst thing this morning and he still looked uncomfortable. He wasn't running around happily, but just stood at the fence swishing his tail and waiting for me to come over. His face looked weird to me. His jaw looked fatter. His nose was still dripping yellow mucus.

Mr. Darcy didn't want to follow me at furst when I put the lead rope on him, but eventually he walked with me for a few minutes. His stride seemed less graceful that it usually is and I wondered if he was in pain. Afterward he seemed out of breath even though it was a short walk. His breathing was very noisy and raspy sounding.

1 took his temperature and found it to be 103.0․ F. His pulse was 44 and his breathing rate was 20. His eyes and ears looked clear. His coat was dirty and his mane was tangled. I brushed him and cleaned his hooves.

I brought some alfalfa hay to the food trough under the roof in the isolation pasture and checked his water bucket. It Looked Like Mr. Darcy wasn't eating or drinking much. I think he had gone to the bathroom out in the fleld. I found where he had gone and didn't see any worms.

I spend an hour patting and talking to Mr. Darcy but he didn't seem very interested in me. He just kept making those strained breathing sounds. 


\section{Horse Disease Information Sheet}

\section{Colic}

Colic refers to any type of abdominal pain, and it can arise for a variety of reasons. Although colic is not technically a disease, it is a dangerous condition that can often turn deadly if untreated. If your horse shows signs of colic, it is important that you talk to your veterinarian immediately.

A horse has small and large intestines that are full of bends called flexures. A horse uses its cecum (see-come) to digest roughage to obtain nutrients. The cecum is a large dead-end chamber that connects to the intestinal tract just after the small intestine and before the large intestine. Since a horse does a lot of digesting in the cecum, the horse's stomach is very small. Horses are also physically incapable of vomiting. All of these characteristics make a horse's digestive system very sensitive.

Colic can result from the ingestion of toxins (any poisonous substance), twisting in the intestines, a mass of food blocking the intestines, a buildup of gas in the intestines, inflammation of the intestines, overstretching of the stomach, or intestinal parasites. Feeding too much grain, too little forage material, changing feed, or changing activity level can contribute to these problems. Symptoms of colic may include

- abnormal behavior such as rolling, kicking (especially at the stomach), lying down more than usual, repeatedly lying down and getting up, lip curling

- standing with the body stretched out

- sweating

- increased heart rate and breathing rate

- reduced digestive sounds

- abnormal bowel activity, constipation

\section{Joint Disease}

Joint disease refers to any type of inflammation (irritation, swelling, or soreness) of the joints, and it can be caused by a variety of factors. A joint is where two bones come together, usually with a cushion of cartilage in between. Inflammation of a joint can result from overexercising, improper exercising, trauma, infection, defects in the bones or cartilage, or from an inherited disorder. Degenerative (dee-jen-er-ah-tive) joint disease, osteochondrosis (austee-oh-kohn-dro-sis), and arthritis are serious joint disease that actually start to destroy the joint.

A horse's leg joints are most prone to injury because they absorb most of the impact of running. What look like knees on a horse's legs are actually the equivalent of human wrists and ankles, making the horse's lower legs the equivalent of human hands and feet. (This means a horse actually runs on the tips of its fingers and toes!) $\mathrm{A}$ horse's front "knee" is called a carpus, and the back "knee" is called a stifle. When someone talks about a horse's knee, they are most likely referring to the carpus. What look like the horse's ankles are called fetlocks. A horse's foot has a pastern between the ankle and the hoof. Joint disease can occur in any joint, but you will usually see it in one of joints mentioned above.

Treatment for joint disease often involves stall rest, application of ice packs, pain medication, and antiinflammatory medication. More serious cases sometimes require surgery. Symptoms of joint disease may include

- swelling around a joint

- stiffness and pain in a joint

- abnormal gait

- joint feels hotter than normal

- decreased performance when exercising

- increased heart rate or breathing rate

- loss of appetite

- depression

\section{Strangles}

Strangles is the common name for a type of bacterial infection that causes swelling in a horse's lymph nodes, which are located underneath its jaw. The disease is very contagious, especially in foals. Transmission can occur through discharge from the nose, from burst lymph nodes, or through contaminated water troughs, feed buckets, brushes, or anything shared between horses. 
A horse diagnosed with strangles must be isolated and allowed to rest for up to 3 months. A veterinarian may use antibiotics to treat the infection. Your horse may be contagious for up to 8 months after contracting the disease, even if it appears healthy.

Strangles can be prevented with proper vaccination. A vaccine is a very effective method to protect against an infection, but it is not a guarantee that your horse will never get the disease. Symptoms of strangles include

- thin nasal discharge that becomes thick and yellow

- enlarged lymph nodes beneath horse's jaw

- strangled breathing sounds

- high fever

- depression

- lack of appetite

\section{Tying-Up Disease}

Tying-up disease is also called exertional (egg-zer-shun-ul) rhabdomyolysis (rab-doe-my-ol-ih-sis), azoturia (a-zoetur-ee-ah), and Monday morning disease. The term "tyingup" refers to a horse that is unwilling to move. Tying-up disease is characterized by the destruction of muscle cells and severe muscle pain. A horse that has been overexerted may "tie-up" without having any muscle damage, much like you may feel sore if you play a game of soccer after sitting on the couch for a week. Horses that actually tie-up are classified as either "sporadic" or "chronic," depending on whether the condition occurs rarely or frequently, respectively.

Sporadic tying-up can be caused by too much exercise for a horse's fitness level, strenuous exercise while a horse has a respiratory infection, electrolyte imbalance, or hypothermia. Nervous horses appear to be more susceptible to tying-up.

Chronic tying-up can be caused by recurrent exertional rhabdomyolysis. Horses with this condition have an abnormality in their muscles that makes the muscles more sensitive to contraction. Afflicted horses tend to be those with a nervous demeanor. Another cause of chronic tying-up is polysaccharide (poly-sack-er-ide) storage myopathy (my-op-pathy). Horses with this condition store sugar in an abnormal form of glycogen in their muscles and have greater than normal levels of glycogen in the muscles. Afflicted horses tend to be calm rather than nervous.

Symptoms of tying-up disease may include

- reluctance to move

- muscle stiffness

- stiff gait

- sweating

- painful muscle contractions

- increased heart rate and breathing rate 


\section{HEALTH ASSESS MENT CHECKLIST}

Horse Name:

Breed:

Gender:

Age:

\section{General Symptoms}

Is there anything you notice that you should be concerned about?

Journal Entry 1:

Journal Entry 2:

Journal Entry 3:

Journal Entry 4:

Journal Entry 5: 
Suspected Diagnosis:

(Use the horse disease information sheet)

\section{Observations}

Explain which symptoms from the above journal helped you indicate a problem, and explain why.

What other observations do you think might be important?

Why do you think recording daily observations of your horse would be helpful in monitoring your horse's health? 


\section{Your Horse’s Health}

\section{Subject Overview and Background Information}

Youth should use the skills and knowledge acquired from the previous activity to assess their horse's health in this application activity. As important as it is to teach the youth about animal health assessments, it is even more vital for the youth to apply their knowledge in the real world. This application activity allows the youth with animals to evaluate their pets' health and determine the right time to consult a veterinarian. The youth should be in a regular habit of checking their animal's overall health and notice any signs of abnormality.

The best way to assess the health of a horse is through observation. There is no clear-cut definition of normal; normal varies from horse to horse, so abnormal depends on your horse as well. Observing your horse daily is the best way to really get to know it and to be able to identify changes that might be symptoms of disease or injury.

In this activity, youth will fill out the health assessment charts used in the previous activity except that they will make observations on their own horses. In addition, they should write a short journal entry on the back of the chart about what they did with their horse daily. The daily observations should last a minimum of 14 days.

Horses can be difficult animals to handle and take vital measurements from. We suggest developing an inexpensive kit that may help the youth in their observation and measuring process. This kit could include the following:

- Latex gloves: for general use every time they examine the horse, especially when they make personal contact with sensitive areas of the horse. Wearing disposable gloves is highly recommended when performing any of these procedures to prevent the spread of disease from human to horse and vice versa.

- Penlight: for use when examining the horse's eyes and nostrils. Encourage youth to note anything that looks abnormal in these areas and compare this with observations from previous days.

- Magnifying glass: for use when looking at the horse's coat. The youth can look closely at the skin and coat and note any interesting observations.
Checking a horse's vitals is important in order to assess its health. Before checking a horse's vitals, make sure the youth understand how to take each of these measurements.

- Respiration (breathing) rate: The average respiration rate of an adult horse is 8 to 15 breaths per minute (foals have higher rates). A horse's respiration rate can change depending on the weather, the amount of exercise it does, and whether it has a fever or is feeling pain. If you notice that your horse's breathing is abnormal or is not quiet while at rest, seek veterinary attention immediately. The respiration rate should never exceed the pulse rate. The time spent inhaling and exhaling should also be equal. To check a horse's respiration rate, watch your horse's ribcage move in and out as it breathes. If it is difficult to see the ribcage clearly, watch the horse's nostrils or place your hand in front of the horse's nostrils. One breath is equivalent to the horse's chest moving in and out once, or one exhalation. Count how many breaths the horse takes in 1 minute; or count the number of breaths it takes in 15 seconds (using a stopwatch or watch with minute hand) and multiply the number by 4 to get the number of breaths in 1 minute.

- Heart rate: The average heart rate for an adult horse is about 30 to 40 beats per minute and around 70 to 120 beats per minute for a foal. A horse's heart rate can change if the horse is exited or nervous, in pain, is exercising, or has a disease. If the heart rate is higher at rest than normal, seek veterinary attention immediately. The higher the heart rate, the more severe the condition. A heart rate from 40 to 60 beats per minute for an adult horse is considered serious, and above 80 is considered critical. To take the heart rate of a horse, use your forefinger to find the major artery that sticks out under the front of the horse's left jawbone. Press against the artery firmly and count the number of beats for 15 seconds, then multiply that number by 4 to obtain the horse's heart rate per minute. Or, if you have a stethoscope, listen to the heart on the left side of the chest just below the left elbow. Remember to count each double "lub-dub" as 1 beat. 
The penlight and magnifying glass can be used to get a closer look at any part of the horse. Do not flash the light directly in the horse's eyes; rather, pass the light back and forth slowly and steadily across the eyes. Do not substitute a laser pointer for the light. The magnifying glass allows youth to take a closer look at the skin and coat, as well as any abnormalities in the ears and mouth.

It is important to let the youth know that they should not make immediate conclusions about their animal's health. Most of them will probably have perfectly healthy horses. We don't want them to get an impression that they are performing analysis to find something wrong with their horses. Emphasize the concept of health care maintenance rather than health diagnosis.

Working with animals can get dirty, so appropriate clothing is required (new clothes are not recommended). Make sure the clothes and shoes are comfortable so that youth can move around and work in them. The recommended dress includes

- closed-toed shoes

- long pants

- long-sleeved shirt

- tie for long hair, if necessary

- no free-hanging earrings

- secure glasses

Since working with horses usually means working outdoors, sun protection is recommended, such as sunscreen and a hat and sunglasses. A painter's mask may be needed by those who are asthmatic, sensitive, or allergic to dust and small particles in the air.

\section{Activity Concepts and Vocabulary}

- Health care maintenance: The regular monitoring of an animal's health.

\section{Life Skills}

- Head: Keeping records, problem solving, decision making, critical thinking

- Heart: Sharing, communication, concern for others, empathy

- Hands: Self-motivation

- Health: Disease prevention, self responsibility, personal safety

\section{Subject Links}

Science and Language Arts

\section{State Content Standards}

\section{Science}

- Third Grade

- Investigation and Experimentation: $5 e$

- Fourth Grade

- Investigation and Experimentation: $6 c$

- Fifth Grade

- Investigation and Experimentation: 6h, 6i

- Sixth Grade

- Investigation and Experimentation: 7d

\section{Language Arts}

- Fourth Grade

- Listening and Speaking Strategies: 1.7

- Fifth Grade

- Listening and Speaking Strategies: 1.5

- Sixth Grade

- Listening and Speaking Strategies: 1.5

\section{Purpose of Activity}

The purpose of this activity is to have youth record observations of their own horse over a period of time. 


\section{$\sim$ ACTIVITY 2 \\ Horse Health Journal}

\section{Overview of the Activity}

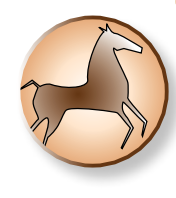

Youth will have the opportunity to assess the health of their horse for a minimum of 14 days.

They will make observations of their horse and record what they observed for each day. They will also write a journal entry each day on their horse's activity. During their group meetings, youth will have a chance to share their observations of their animal and discuss any potential diseases or illnesses with their group.

\section{Time Required}

Approximately 15 minutes daily for at least 2 weeks

\section{Suggested Grouping}

Individual

\section{Materials Needed for Each Individual}

(*Materials provided in curriculum)

- Flip chart paper

- *Animal health journal

- Animal background information sheet

- Animal health daily recording sheet for each day of observation

- Health assessment kit:

- Latex (disposable) gloves

- Penlight

- Magnifying glass

- Writing tool (pencil, pen, etc)

- Stopwatch or watch with second hand

- Disinfectant

- Stethoscope

- Painter's mask (if sensitive or allergic)

- Tape measure

- Rectal thermometer

- Lubricant

\section{Getting Ready}

Each youth is expected to observe their horse for 14 to 28 days. Make an animal health journal for each youth, which consists of an animal background information sheet and one animal health daily recording sheet for each day the youth will observe their horse.

\section{Opening Questions}

Ask the youth to respond to each question below by sharing their ideas verbally and/or by recording them on the flip chart paper provided.

1. When you are sick, what observations might your parents make that would lead them to take you to see the doctor?

2. Describe what you might notice about horses that are not feeling well.

3. What kinds of observations about your horse would prompt you to call your veterinarian?

4. Why might keeping a daily journal about you or your horse be helpful to a doctor or veterinarian?

\section{Procedure (Experiencing)}

1. Give each individual an animal health journal packet, which includes an animal background information sheet and one animal health daily recording sheet for each day of observation.

2. Review the terms on the checklist and how to properly take the heart rate and respiration rate. Make sure the youth know the proper dress code for working with animals.

3. Explain to the youth that they are to fill out the animal background information sheet. If they have more than one animal, they may choose one to work with for this activity. They may need to work with their parents to answer the background information questions. 
4. Youth will also fill out an animal health daily recording sheet every day for the chosen number of days ( 14 days are recommended). The youth should also include a brief journal entry on the back of the recording sheet, describing what they did with their animal each day.

5. Ask the youth to prepare to share a report with their peers at the next group meeting. Reports should include an oral description on observations along with any potential symptoms of illness. Youth may want to graph heart rates or respiration rates. Youth who have a foal or young horse may want to graph growth. Youth could also create a poster or PowerPoint presentation to share their findings.

\section{Sharing, Processing, and}

\section{Generalizing}

Have each youth share his or her report with the group.

Follow the lines of thinking developed through the general thoughts, observations, and questions raised by the youth. If necessary, use more targeted questions as prompts to get to particular points:

1. What are some advantages of keeping a daily health journal for your horse? Were there any challenges? Please explain.
2. Did your horse present any symptoms of concern? If so, what were they, and what did you do?

3. In what ways are graphs of heart rate or respiration rate helpful in assessing your horse's health? What kind of information can you get from a growth chart? Please explain.

4. What similarities, if any, were there between your horse and others' horses? What differences, if any, were there? Please explain.

\section{Concept and Term Discovery/ Introduction}

Volunteers need to ensure that the concept of health care monitoring has been introduced or discovered by the youth.

- Note: The goal is to have the youth develop concepts through their exploration and define terms using their own words.

\section{References}

Bayer Equine Connection Web site, http://www. bayerequineconnection.com/.

eHow.com. How to measure a horse's respiration rate. eHow.com Web site, http://www.ehow.com/ how_2739_measure-horses-respiration.html.

Equine Vetrinary Services. Vital signs. Equine Veterinary Services Web site, http://www.equinevetservice.com/ vitalsigns.htm.

Huntington, P., J. Myers, and E. Owens. 2004. Horse sense: The guide to horse care in Australia and New Zealand. Collingwood, Australia: Landlinks Press.

Sutor, C. 1997. Vital signs. Equusite Web site, http://www. equusite.com/articles/health/healthVitalSigns.shtml. 


\section{Animal Health Journal}

\section{ANIMAL BACKGROUND INFORMATION SHEET}

Date:

Youth's name:

Animal's name:

Species:

Breed: Date of birth or age of animal:

Gender (male, female, or unknown/fixed or intact): Has this animal been bred?

If yes, how many times? Date of last breeding?

Health history: Is this animal on any medications? If yes, please list.

Does this animal have current vaccinations?

Does this animal have any allergies? If yes, please list.

Has this animal had any major illnesses or surgeries? If yes, describe.

Date of last veterinary checkup:

Environment: Please describe the housing for this animal (indoor/outdoor, with other animals/alone, size of pen or enclosure).

Diet:Please describe the diet and the feeding schedule for this animal. Describe how water is provided (bucket/trough, automatic waterer, etc.) 


\section{ANIMAL HEALTH DAILY RECORDING SHEET}

Date:

Animal name:

\section{MEASUREMENTS}

Heart rate:

\section{OBSERVATIONS}

Behavior:

Activity level:

Appetite:

Body condition:

Posture and gait:

Skin, coat, and hooves:

Eyes:

Ears:

Nose:

Body waste:

Other:
Time:

Respiration (breathing) rate: 


\section{APPENDIX}

The activities in this curriculum are designed around inquiry and experiential learning. Inquiry is a learnercentered approach in which individuals are problem solvers investigating questions through active engagement, observing and manipulating objects and phenomena, and acquiring or discovering knowledge. Experiential learning $(\mathrm{EL})$ is a foundational educational strategy used in $4-\mathrm{H}$. In it, the learner has an experience phase of engagement in an activity, a reflection phase in which observations and reactions are shared and discussed, and an application phase in which new knowledge and skills are applied to a real-life setting. In 4-H, an EL model that uses a 5-step learning cycle is most commonly used. These five steps-Exploration, Sharing, Processing, Generalizing, and Application-are part of a recurring process that helps build learner understanding over time.

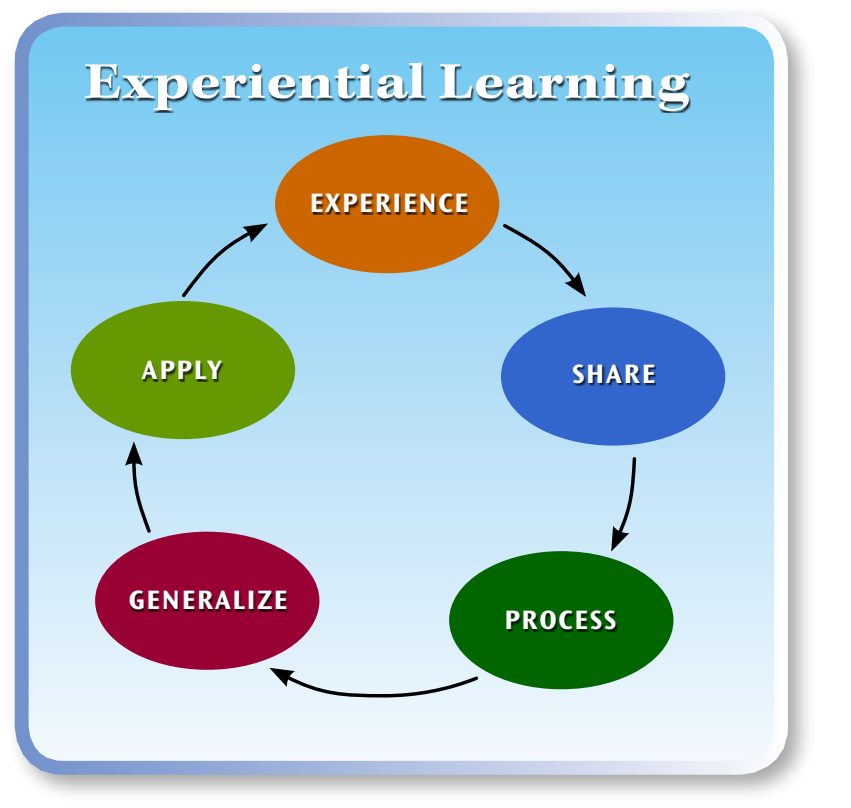

For more information on inquiry, EL and the 5-step learning cycle, please visit the University of California's Science, Technology, Environmental Literacy Workgroup's Experiential Learning Web site, http://www. experientiallearning.ucdavis.edu/default.shtml.

\section{For Further Information}

To order or obtain ANR publications and other products, visit the ANR Communication Services online catalog at http://anrcatalog.ucdavis.edu or phone 1-800-994-8849. You can also place orders by mail or FAX, or request a printed catalog of our products from

University of California

Agriculture and Natural Resources

Communication Services

6701 San Pablo Avenue, 2nd Floor

Oakland, California 94608-1239

Telephone 1-800-994-8849

510-642-2431

FAX 510-643-5470

E-mail: danrcs@ucdavis.edu

(C)2009 The Regents of the University of California

Agriculture and Natural Resources

All rights reserved.

No part of this publication may be reproduced, stored in a retrieval system, or transmitted, in any form or by any means, electronic, mechanical, photocopying, recording, or otherwise, without the written permission of the publisher and the authors.

Publication 8346

ISBN-13: 978-1-60107-591-8

The University of California prohibits discrimination or harassment of any person on the basis of race, color, national origin, religion, sex, gender identity, pregnancy (including childbirth, and medical conditions related to pregnancy or childbirth), physical or mental disability, medical condition (cancer-related or genetic characteristics), ancestry, marital status, age, sexual orientation, citizenship, or service in the uniformed services (as defined by the Uniformed Services Employment and Reemployment Rights Act of 1994: service in the uniformed services includes membership, application for membership, performance of service, application for service, or obligation for service in the uniformed services) in any of its programs or activities.

University policy also prohibits reprisal or retaliation against any person in any of its programs or activities for making a complaint of discrimination or sexual harassment or for using or participating in the investigation or resolution process of any such complaint.

University policy is intended to be consistent with the provisions of applicable State and Federal laws.

Inquiries regarding the University's nondiscrimination policies may be directed to the Affirmative Action/Equal Opportunity Director, University of California, Agriculture and Natural Resources, 1111 Franklin Street, $6^{\text {th }}$ Floor, Oakland, CA 94607, (510) 987-0096. For information about ordering this publication, telephone 1-800-994-8849. For assistance in downloading this publication, telephone 530-754-3927.

An electronic copy of this publication can be found at the ANR Communication Services catalog Web site, http://anrcatalog.ucdavis.edu.

\section{UCE}

REVIEWED This publication has been anonymously peer reviewed for technical accuracy by University of California scientists and other qualified professionals. This review process was managed by the ANR Associate Editor for Human and Community—Youth Development.

pr-3/09-SB/RW 